\title{
os senhores e a distribuição da propriedade escrava no Rio de Janeiro do século XIX.*
}

Luiz Carlos Soares

Departamento de História - UFF

"O branco foi feito para comandar e descansar, o negro para obedecer e trabalhar". Era assim que os senhores de escravos de todo o Brasil se expressavam, revelando sua concepção geral de organização do trabalho e da sociedade ou a "fórmula filosófica da sociedade brasileira", como tão bem registrou o viajante francês Charles Expilly.

Um pouco antes de Expilly, o viajante anglo-americano Thomas Ewbank havia constatado a generalização da escravidão negra em todo o Brasil e a sua "inevitável tendência" para "tornar o trabalho uma atividade desonrosa", procurando analisar detalhadamente a idéia de trabalho desenvolvida pelas "classes privilegiadas" do País:

"A escravidão negra é regra no Brasil, e os brasileiros se retraem como que horrorizados ante qualquer emprego manual. Dentro do espírito das classes privilegiadas de outros países, dizem os brasileiros que não nasceram para trabalhar, mas para mandar. Pergunte-se a um jovem brasileiro de família respeitável porém em más condições econômicas por que não aprende um ofício e passa a ganhar sua vida com independência, e, nove vezes em dez, ele tremerá de indigna-

Este artigo é parte do Capítulo III ("Masters and slaves in nineteenth-century Rio de Janeiro") da tese de doutoramento intitulada Urban Slavery in Nineteenth-century Rio de Janeiro, defendida em janeiro de 1988, no University College London (Universidade de Londres).

Expilly, Charles - La traite, l'immigration et la colonisation au Brésil. Paris, A. Lacroix, Verboeckhoven et Cie., Editeurs, 1865, p. 16. 
ção, e perguntará se se quer insultá-lo! 'Trabalhar!? Trabalhar!? redarguiu um deles — Temos os negros para isso'".

Ao descrever o "horror" que os brasileiros brancos nutriam diante da perspectiva de executarem qualquer tipo de trabalho braçal, Ewbank ilustrou sua narrativa com alguns casos, como o de umjovem pobre cuja mãe rejeitou a sugestão de um médico estrangeiro amigo para que lhe fosse ensinado algum ofício manual, mas depois conseguiu arranjar-lhe uma "colocação" como amanuense da polícia do município do Rio de Janeiro (Corte) com um modesto salário,para a época (1846), de 300 mil réis anuais. Um outro caso contado por Ewbank era o de um rapaz de 18 anos que foi trabalhar num estabelecimento comercial do centro do Rio de Janeiro e o patrão lhe pediu para levar, a uma firma vizinha, um pacote um pouco maior do que uma carta. O rapaz, depois de meditar por algum tempo,"saiu porta afora e (...) chamou um negro, que atrás dele levou o pacote ao destinatário". ${ }^{3}$

Casos como estes foram freqüentemente narrados por viajantes estrangeiros que estiveram no Rio de Janeiro, sobretudo na primeira metade do século XIX, alguns deles indignados com a pretensiosa atitude daqueles setores que tinham o controle real da economia e dirigiam os destinos da sociedade brasileira, atitude esta que contagiava também as camadas livres pobres do País. Se era a propriedade escrava que conferia aos indivíduos brancos (descendentes dos colonizadores portugueses e estrangeiros que viviam no País) uma posição de mando e status social, conseqüentemente mais poderio e prestígio teriam aqueles indivíduos que possuíssem um maior número de escravos para prover o sustento e a riqueza de sua família. Donde se conclui que o "nãotrabalhar", antes de indicar uma atitude de aversão ou desamor ao trabalho, era muito mais um indicador da posição e prestígio dos indivíduos na sociedade brasileira.

Por outro lado, é importante frisar que, nas cidades, a propriedade escrava era um fenômeno tão generalizado que ultrapassava os limites da "fórmula filosófica" criada pelos grupos dirigentes. Para desagrado de muitos brancos, indivíduos com outra origem étnico-racial (negros

Ewbank, Thomas - A Vida no Brasil ou Diário de uma Visita ao Pais do Cacau e das Palmeiras, Volume I. Tradução de Homero de Castro Jobim. Rio de Janeiro, Editora Conquista, 1973, p. 179.

Idem.p. 180 . 
e mestiços libertos) também foram senhores de escravos e muitas vezes compartilhavam com os brancos a visão de mundo destes. No caso dos mestiços (mulatos) mais claros, muitos deles procuravam até passar-se por brancos. A própria dinâmica da sociedade escravista criou me canismos de "branqueamento" para facilitar a ascensão de certos indivíduos mestiços, tal como aconteceu com o grande escritor mulato Machado de Assis. Estes podiam não ter a pele branca, mas eram reconhecidos como "socialmente brancos". Não podemos esquecer também que estes mecanismos acabavam por tornar menos rígida a dicotomia social senhores-escravos. Se nos extremos sociais encontramos, sobretudo na primeira metade do século XIX, estas duas classes, é importante assinalar que nos seus interstícios viviam indivíduos livres, mas despossuídos de escravos, muitos deles negros e mestiços egressos do cativeiro ou filhos de país já libertos.

Além disso, mesmo entre os brancos, existiam "brancos" e "brancos". Estes eram por excelência os senhores de escravos, mas isso não significava que todos os indivíduos dessa cor tivessem o mesmo poderio econômico, político e social. Existiam aqueles que, por possuírem mais escravos e outros meios de produção, tinham efetivamente o controle da vida política nos níveis local, regional e, depois da Independência, nacional. Não era mera coincidência que o sistema de participação política da população livre, durante o Império, estivesse baseado em critérios censitários, que requeriam dos cidadãos brasileiros diferentes níveis de rendimento anual para a escolha e o exercício dos diferentes níveis de poder. Seria apropriado falarmos em brancos mais ricos, com um maior nível de participação e influência política, e brancos mais pobres, com uma participação limitada e sem nenhuma influência política, inclusive muitos deles totalmente despossuídos de escravos. Entretanto, o discurso ideológico produzido pelos grupos mais ricos e influentes procurava criar uma identidade entre os diversos segmentos brancos, sendo a base de articulação deste discurso a definição do trabalho como uma atividade exclusiva dos negros escravos, que deveriam prestar obediência irrestrita aos seus senhores brancos, que, por sua posição de mando, ocupavam o lugar mais importante na sociedade.

Até mesmo a Igreja Católica e o Estado encontravam-se entre os grandes proprietários de escravos no Rio de Janeiro. As diversas ordens religiosas existentes na cidade eram proprietárias de uma grande quantidade de cativos, empregados em seus serviços domésticos ou como pedreiros, carpinteiros, marceneiros, carregadores, etc, como aponta- 
ram diversos visitantes estrangeiros. Já o Estado Imperial, como decorrência da influência que os grandes senhores de escravos tinham sobre ele, não se furtou a possuir escravos. Em diversos estabelecimentos e repartições estatais da Corte e das Províncias, os "escravos da nação" foram utilizados até 1871 , quando em 28 de setembro, por ocasião da promulgação da Lei do Ventre Livre, eles foram libertados. No final dos anos 1840 e início dos anos 1850 , mais de duzentos "escravos da nação" eram empregados pelo Estado na Corte, distribuídos pelo Arsenal de Guerra, Arsenal de Marinha, Jardim Botânico, Hospital Militar, Palácio da Quinta da BoaVista, etc. As vésperas de sua libertação, no início de 1871 , ainda restavam 34 "escravos da Nação" trabalhando na Corte."

A generalização da propriedade escrava no Rio de Janeiro da primeira metade do século XIX, entre os diversos segmentos da população livre, dos mais ricos aos mais pobres, pode ser demonstrada com o estudo dos Inventários Post-Mortem do acervo do Arquivo Nacional do Rio de Janeiro. ${ }^{6}$ Para isso, realizamos uma amostragem com duzentos inventários relativos ao período 1810-1849, cujos inventariados falecidos residiam na cidade do Rio de Janeiro ou nas suas cercanias mais imediatas. Para consulta dos inventários, tivemos que definir certos critérios ou procedimentos estatísticos. Em primeiro lugar, como o período acima mencionado abrange quatro décadas, foram consultados exatamente cinqüenta inventários por década. Em segundo lugar, como a proporção sexual entre a população livre no período era aproximadamente $60 \%$ de ho-

\footnotetext{
Ewbank - Op. cit., Volume II, pp. 327, 330 e 341. As ordens religiosas possuíam quantidades ainda maiores de escravos, empregados nos trabalhos da lavoura, em suas propriedades rurais na província do Rio de Janeiro. Ewbank chega a mencionar a existência de uma fazenda em Macacú,pertencente aos Carmelitas, que achavam "mais lucrativo ocupar-se com a criação de negros do que produzir café ou qualquer outro produto" (Idem, p. 360).

"Paraná, Marquês de - Proposta e Relatorio apresentado á Assembléa Geral Legislativa pelo Ministro c Secretario d'Estado dos Negocios da Fazenda, Tabella No. 43. Rio de Janeiro, 1855, p. s/no; e Rio Branco,Visconde do - Proposta e Relatorio apresentado á Assembléa Geral Legislativa pelo Ministro e Secretario d'Estado dos Negocios da Fazenda, Tabella No. 66. Rio de Janeiro, 1871, p. s/no.

É importante assinalar que entre os setores livres mais pobres existiram muitos indivíduos que não chegaram a fazer inventários ou testamentos pelo fato de que nada tinham a deixar para seus filhos, esposas ou parentes mais próximos. Estes indivíduos (alguns brancos, mestiços e libertos) viviam, com suas famílias, numa situação de pobreza absoluta, sem a possibilidadede adquirir um ou dois escravos e colocá-los como fontes de rendimento.
} 
mens e $40 \%$ de mulheres (ver Tabela I), foram selecionados a mesma proporção de inventários de homens e mulheres por década, ou seja, trinta inventários de homens e vinte de mulheres, tendo-se 120 inventários de homens e oitenta de mulheres para todo o período supramencionado. Os inventários de mulheres foram consultados porque, apesar do caráter patriarcal da sociedade brasileira e do maior poderio dos homens, existiram mulheres que foram responsáveis pela administração do patrimônio de suas famílias, como as viúvas que herdavam bens dos seus falecidos maridos ou mesmo mulheres solteiras que reuniam sob sua tutela irmãos mais novos, sobrinhos, afilhados ou agregados.

Tabela I. População do Município da Corte: 1849-1872.

\begin{tabular}{|c|c|c|c|c|c|}
\hline \multicolumn{3}{|c|}{1849} & \multicolumn{3}{|c|}{1872} \\
\hline \multicolumn{2}{|c|}{ Livres } & \multirow{2}{*}{$\begin{array}{c}\% \\
56,06\end{array}$} & \multicolumn{2}{|c|}{ Livres } & \multirow{2}{*}{$\begin{array}{c}\% \\
59,23\end{array}$} \\
\hline Homens & 87.374 & & Homens & 133.880 & \\
\hline Mulheres & 68.490 & 43,94 & Mulheres & 92.153 & 40,77 \\
\hline Total & 155.864 & 100 & Total & 226.033 & 100 \\
\hline \multicolumn{2}{|c|}{ Escravos } & $\%$ & \multicolumn{2}{|c|}{ Escravos } & $\%$ \\
\hline Homens & 65.591 & 59,30 & Homens & 24.886 & 50,85 \\
\hline Mulheres & 45.011 & 40,70 & Mulheres & 24.053 & 49,15 \\
\hline Total & 110.602 & 100 & Total & 48.939 & 100 \\
\hline Total C & 26 & & Total & al & \\
\hline
\end{tabular}

Fontes: Herman Burmeister - Viagem ao Brasil através das Províncias do Rio de Janeiro e Minas Gerais. Tradução de Manoel Salvaterra e Hubert Schoenfeldt. São Paulo, Livraria Martins, 1952, p. 325; Recenseamento da População do Municipio Neutro de 1872. Rio de Janeiro, 1873.

Dos duzentos inventariados, apenas 37 (17,50\%) não possuíam escravos. Destes, 24 inventariados eram indivíduos cujas ocupações não foram identificadas e onze tiveram suas ocupações conhecidas (ver Tabela II). Provavelmente, os inventariados sem ocupação identificada deviam ser indivíduos muito pobres, pois, nas suas relações de bens constavam apenas pequenas somas de dinheiro ou objetos pouco valiosos, tais como móveis velhos, jóias ordinárias, alguns poucos objetos de ouro ou prata, etc. Isso mostra que, apesar da extensão, da propriedade escrava às camadas mais pobres da população, existiam aqueles setores que viviam miseravelmente, sem meios de vida, ocupação ou profissão definida e impossibilitados de adquirir o elemento cativo. Ewbank teve a oportunidade de ver um indivíduo nesta situação, bem próximo da indigência, perambulando pelas ruas do Rio de Janeiro. Tratava-se de um homem branco, que se recusava a trabalhar porque 


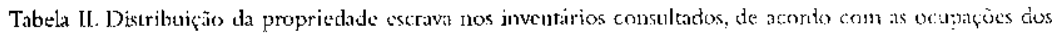
inventariados: 1810 - 1849 .

Ocupação

Vivian dos Rendimentos Profissionais

Funcionários Públicos/Fazendeiros

Comerciantes

Industriais

Advogados

Médicos

I'rofessores

Religiosos

Oticiais Militares

Oficiajs Militares/ Lavtadores

Militares Subalteruns

Militares Subalternos/Negrociantes

Militares Subalternos; I.avradores

Lavradores

Boticários

Arresàos
Número de Escravos Possuídos

Total

$\begin{array}{llllllllll}0 & 1 & 3 & 6 & 11 & 21 & 31 & 41 & 51 & 100\end{array}$

$\begin{array}{llllllll}2 & 5 & 10 & 20 & 30 & 40 & 50 & 100+\end{array}$

\begin{tabular}{lllllllllllll} 
Total & 4 & 6 & 10 & 15 & 16 & 3 & 2 & - & - & 1 & 57 \\
\hline
\end{tabular}

Viviam dos Rendimentos Profissionais, Aluguéis de Imóveis e/on Dividendos de Capital

Fazendeiros/Comerciantes/Senhorjos

Fazendeiros/Senhorios

Militares Sulbalternos/Fazendeiros/Senhorios

Oticiais Militares/Senhorios

Lavradores/Sentorios

Comerciantes/Senhorios

Total

\begin{tabular}{lllllllllll}
- & - & - & - & - & - & - & - & 1 & - & 1 \\
- & - & - & - & - & - & - & - & 1 & - & 1 \\
- & - & - & - & - & - & - & - & - & 1 & 1 \\
- & - & - & - & 1 & - & - & - & - & - & 1 \\
- & - & - & - & - & 1 & - & - & - & & 1 \\
- & - & 1 & - & - & - & - & - & - & - & 1 \\
- & - & 1 & - & 1 & 1 & - & - & 2 & 1 & 6 \\
\hline
\end{tabular}

Viviam Exclusisamente dos Rendimentos de

\begin{tabular}{|c|c|c|c|c|c|c|c|c|c|c|c|}
\hline Escravas & - & 7 & 15 & 12 & 6 & 2 & - & - & - & - & 42 \\
\hline Total & - & 7 & 15 & 12 & 6 & 2 & - & 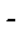 & - & - & 42 \\
\hline
\end{tabular}

Viviam dos Rendimentos de Escravos, Aluguéis de Imóveis elau Dividendos de Capital

Explotadores dos Rendimentos de Escravos/

Senhorios

Exploradores dos Rendimentos de Escravos/

Capitalistas

Exploradores dos Remdiumentos de Escravos/

Senhorios/Capitalistas

Total

\begin{tabular}{rrrrrrrrrrr}
- & 2 & 4 & 11 & 4 & 1 & 1 & - & - & - & 23 \\
- & 1 & 2 & - & - & 1 & - & - & - & - & 4 \\
- & - & - & - & 1 & - & - & - & - & - & 1 \\
\hline & 3 & 6 & 11 & 5 & 2 & 1 & - & - & - & 28
\end{tabular}

Viviam dos Rendimentos de Aluguéis de Imóveis el on Dividendos de Capital

Senhorios

Ciapitalistils

Seuhorios/Capitalistas

Total

Sem Ocupaçäo Declarada

Total

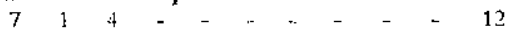

$\begin{array}{rrrrrrrrrrr}7 & - & - & - & - & - & - & - & - & 1 \\ - & 1 & - & - & - & - & - & - & - & - & 1\end{array}$

Total Geral

$734-5-5-5-14$

$24 \quad 11144-5 . \quad-\quad-\quad-5.3$

$2411144 \quad-\quad-\quad-\quad-\quad-53$

FONTE: Arquivo Nacional do Rio de Janeiro - Inventários "Post-Mortem". Para os Anos 1810-1849. 
considerava o trabalho degradante, vivendo num "estado de degenerescência pior que os costumes dos selvagens". E o viajante completava:

"Era a imagem da preguiça, da sujeira e do desânimo: um espécime, ao que dizem, de milhares existentes no Brasil, a quem a escravidão, com os sentimentos que faz nascer, transforma em destroços".

Dos 165 inventariados possuidores de escravos (82,50\% do total), apenas 53 viviam exclusivamente da sua ocupação profissional, empregando seus cativos em serviços domésticos ou nas próprias atividades que exerciam, alugando-os a terceiros ou pondo-os ao ganho de rua apenas secundária e esporadicamente. Entre estes 53 inventariados encontramos desde um alto funcionário público - que também era fazendeiro - diversos comerciantes, profissionais liberais, oficiais militares e subalternos, boticários, prósperos lavradores dos subúrbios e das cercanias da cidade, até indivíduos mais humildes como três pequenos lavradores e um artesão. Os inventariados que viviam da sua profissão, mas tinham outras fontes de renda tais como aluguéis de imóveis e rendimentos de capital, eram apenas seis. (Ver Tabela II).

Se fossemos definir a ocupação estritamente como sinônimo de profissão, um grande número de inventariados não teria ocupação alguma. Todavia, como na sociedade escravista a atitude de aversão ao trabalho era a regra, muitos indivíduos afastavam qualquer possibilidade de exercerem até mesmo atividades profissionais mais respeitadas como a advocacia, a medicina, o funcionalismo público, a carreira militar e o magistério. Entretanto, eles eram obrigados a ter meios que garantissem sua sobrevivência e lhes possibilitassem manter uma atitude de horror a qualquer tipo de trabalho. Apesar de viverem ociosamente, estes indivíduos tinham algumas ocupações, administrando o aluguel de seus imóveis, o aluguel de seus escravos a terceiros ou o seu emprego no ganho de rua, e, em menor escala, os rendimentos do capital que investiram na aquisição de algumas apólices da dívida pública e ações do Banco do Brasil e de algumas poucas empresas dos anos 1840. Ao todo, 77 inventariados viviam dessas ocupações, o que em termos de uma amostragem estatística é um número bastante significativo, eqüivalendo a 46,66 \% dos inventariados pos-

Ewbank - Op. cit. .Volume II, p. 389. 
suidores de escravos e 38,50\% dos inventariados escolhidos para o período 1810-1849 (verTabela II). É de se supor que a proporção dos indivíduos que tinham estes meios de vida fosse muito grande no Rio de Janeiro da primeira metade do século XIX.

Desses 77 inventariados, a grande maioria vivia unicamente da exploração do aluguel de escravos ou de escravos de ganho, sendo seu número 42. Outros 32 indivíduos, além de explorarem o aluguel de escravos ou escravos de ganho, viviam também dos rendimentos do aluguel de imóveis, enquanto quatro indivíduos exploravam seus cativos nas modalidades mencionadas e tinham também rendimentos de capital. Somente um inventariado explorava as três formas de obtenção de renda conjugadamente. Por fim, podemos mencionar mais sete inventariados que possuíam alguns poucos escravos, mas não viviam da sua exploração: cinco deles viviam dos aluguéis de imóveis, um de rendimento de capital e um último era sustentado simultaneamente por estas duas formas de obtenção de renda. (Ver Tabela II).

Foram encontrados também alguns inventariados possuidores de escravos sem ocupação identificada. Seu número é 29, e existe uma grande possibilidade de muitos deles terem vivido exclusivamente da exploração do aluguel ou ganho de seus cativos, pois estes foram o único bem relacionado nos seus inventários, ao lado de objetos sem nenhum valor. (Ver Tabela II).

Com relação à distribuição da propriedade escrava entre os 165 senhores inventariados, pode-se dizer que a grande maioria deles possuía entre um a dez escravos. Seu número chegava a 122 e correspondia a 73,94\% dos possuidores de cativos. Entre estes "pequenos escravistas", para utilizar uma expressão cunhada pelo historiadorJoão José Reis, trinta possuíam entre um e dois escravos, cinqüenta entre três e cinco escravos e 42 entre seis e dez escravos. Apenas 43 indivíduos ( $26,06 \%$ dos senhores inventariados) possuíam acima de dez escravos. Entre eles, a distribuição da propriedade escrava era muito desigual, possuindo 28 inventariados entre onze e vinte escravos, oito entre 21 e trinta escravos, três entre 32 e quarenta escravos, dois entre 71 e cem escravos e dois acima de cem escravos. Estes quatro últimos inventariados, apesar de residirem na cidade do Rio de Janeiro, eram grandes fazendeiros nas freguesias de fora da cidade, como indica o grande número de escravos que possuíam, pois apenas excepcionalmente, o que se reflete em nossa amostragem, alguns indivíduos possuíam mais de trinta ou quarenta escravos no ambiente urbano. Isto é válido, inclusive, para os mais prósperos lavradores que desenvolviam 
suas atividades agrícolas nas freguesias suburbanas e rurais do Município da Corte. ${ }^{8}$ (Ver Tabela II).

Nos inventários desta amostragem, foram relacionados e avaliados 1.737 escravos. Se quiséssemos estabelecer a média de escravos possuídos por cada inventariado, esta seria de 8,68 para todo o período 1810-1849. Contudo, o mais correto seria estabelecer uma média por década, levando-se em consideração que foram consultados cinqüenta inventários decenalmente, e, em nosso caso, as médias obtidas se tornariam extremamente reveladoras. Assim, dos 357 escravos avaliados em 1810-1819, teríamos uma média de 7,14 cativos para cada inventariado. Para 1820-1829, foram avaliados ao todo 412 escravos, o que daria uma média de 8,24 cativos para cada inventariado. Nos inventários de 1830-1839, foram avaliados um total de 414 escravos o que corresponderia a uma média de 8,28 cativos para cada inventariado. Já nos inventários de 1840-1849, foram avaliados 554 escravos e a média seria a mais elevada de todas as décadas, correspondendo a 11,08 cativos para cada inventariado. (Ver TabelaVI). Convém assinalar que a média dessa última década reflete a existência de um acentuado número de escravos no Rio de Janeiro, em virtude do ritmo frenético do tráfico africano nos seus últimos dez anos, abarrotando os mercados da cidade e propiciando um aumento do número de escravos possuídos pelos senhores da Corte."

O número de cativos possuídos por cada um dos inventariados da

\begin{abstract}
${ }^{8}$ A amostragem organizada porJoãoJosé Reis para a cidade de Salvador na primeira metade do século XIX, com base em inventários post-mortem e testamentos, apresenta resultados muito próximos dos que obtivemos em nossa amostragem para o mesmo período. Dos 395 inventariados da amostragem dos historiador baiano, 343 eram possuidores de escravos $(86,84 \%)$ e apenas 52 não possuíam escravos $(13,16$ $\%)$. Entre os 343 proprietários de escravos, 256 possuíam entre um e dez cativos $(74,64 \%)$, enquanto que somente 87 deles possuíam acima de 10 cativos $(25,36 \%)$. Em Salvador, os "pequenos escravistas" também formavam a grande maioria dos senhores de escravos. (Reis - Rebelião Escrava no Brasil.A história do levante dos malês (1835). São Paulo, Editora Brasiliense, 1986, pp. 24-26.

"Sobre o tráfico de escravos africanos na primeira metade do século XIX, ver:Taunay, Affonso de E. - "Subsídios para a história do tráfico africano no Brasil", em Anais do Museu Paulista, X. São Paulo, Museu Paulista, 1941, p. 305; Goulart, Maurício A Escravidão Africana no Brasil. Das origens à extinção do trafico. São Paulo, Editora AlfaOmega, 1975; Bethell, Leslie M. - A Abolição do Tráfico de Escravos no Brasil. Tradução de Vera Neves Pedroso. Rio de Janeiro - São Paulo, Editora Expressão e Cultura - EDUSP, 1976; e Conrad, Robert E. - Tumbeiros. O tráfico de escravos para o Brasil. Tradução de Elvira Serápicos. São Paulo, Editora Brasiliense, 1985.
\end{abstract}


nossa amostragem indica muito bem a sua condição e talvez venha refletir os padrões de propriedade escrava entre as diversas categorias da população livre do Rio de Janeiro na primeira metade do século XIX. Vimos que 35 inventariados não possuíam escravos e talvez 24 deles vivessem numa situação de pobreza absoluta. Entretanto, outros inventariados conseguiram escapar dessa situação pela posse de um, dois ou mais escravos, que rotineira ou esporadicamente forneciam sustento para eles e suas famílias e ainda desempenhavam as tarefas domésticas em suas casas. Este era o caso de pelo menos 59 dos 80 inventariados que possuíam de um a cinco escravos. Estes indivíduos desempenhavam atividades profissionais mais humildes ou então viviam do aluguel ou ganho dos seus cativos, em alguns casos complementando seus rendimentos com aluguéis de algum imóvel. Os outros 21 inventariados, apesar de possuírem também entre um e cinco escravos, viviam mais folgadamente pelo fato de terem maiores rendimentos oriundos de suas ocupações profissionais, aluguéis de imóveis ou de investimentos de capital. Apesar de encontrarmos entre esses inventariados alguns profissionais liberais e oficiais militares, cujas profissões já eram mais reconhecidas socialmente, eles não conseguiam escapar da classificação de "pobres", estabelecida na primeira metade do século XIX, quando o prestígio pessoal e a posição na hierarquia social eram medidos pelo número de escravos possuídos. (Ver Tabela II).

A situação dos pobres possuidores de um ou dois escravos era bem exemplificada pelas relações de bens inventariados de Joaquina Franscisca do Nascimento, falecida em 1829, e Francisca Ignacia Jerônima Botelho, falecida em 1833. Ambas possuíam apenas dois cativos que forneciam o sustento de suas famílias. Situação interessante era a de Augusto Cezar de Souza, falecido em 1849, que possuía dois escravos, mas também vivia de dividendos fornecidos por algumas apólices, possuindo ainda alguns objetos de ouro e prata. Entre os indivíduos pobres que viviam mais folgadamente se encontravam os inventariados José Rodrigues e José Alexandre Marques. O primeiro inventariado faleceu em 1834, deixando a seus herdeiros uma casa com um pequeno terreno no centro da cidade e quatro escravos. Já o segundo inventariado era artesão-sapateiro e morreu em 1846, deixando a seus herdeiros uma casa na Rua do Conde, matérias-primas, ferramentas e três escravos que desempenhavam o mesmo ofício. ${ }^{10}$

"Arquivo Nacional do Rio de Janeiro (doravante citado como ANRJ) — Inventários 
Ewbank pôde perceber muito claramente a predominância dos indivíduos pobres entre os proprietários de escravos e chegou a dizer que, para "centenas e centenas de famílias", os rendimentos originários do aluguel ou do ganho de um ou dois escravos se constituíram na "sua única fonte de sustento"." Antes de Ewbank, nas primeiras décadas do século XIX, o comerciante inglês John Luccockjá tinha mencionado a prática bastante generalizada dos senhores que ensinavam ou mandavam ensinar ofícios mecânicos e serviços domésticos aos seus escravos para vendê-los ou alugá-los posteriormente, constituindo-se os rendimentos oriundos desta atividade na sua fonte exclusiva de sustento:

"Toda a casa que se prezava era provida de escravos aos quais se haviam ensinado algumas ou mais artes comuns na vida, e que não somente trabalhavam nessas especialidades para a família a que pertenciam, como eram também alugados pelos seus senhores a pessoas não tão bem providas quanto aqueles. Não conseguiam ganhar muito; em 1808, considerava-se um operário bem pago, com meia pataca, menos que um xelim, por dia. Mas, o afluxo de estrangeiros e a multiplicação das necessidades, dentro em pouco, elevaram o valor do trabalho, e em grau extravagante. Deu isso motivo a que surgisse uma nova classe social, composta de pessoas que compravam escravos para o fim especial de instruí-los nalguma arte útil ou ofício, vendendo-os em seguida por preço elevado, ou alugando seus talentos e trabalho". ${ }^{2}$

Esta dependência dos rendimentos oriundos do trabalho dos seus poucos escravos fez com que duas pobres senhoras recorressem desesperadamente à Câmara Municipal da Corte, no decorrer do ano de 1842, na ocasião da prisão de escravas suas que desrespeitaram as posturas municipais. A primeira delas era Agostinha Maria, moradora na Rua do Sabão, que teve sua única escrava Maria Cabinda presa e recolhida ao Depósito Público por terjogado lixo no Largo da Cadeia Nova. A

"post-mortem": $\quad$ Caixa 6581 - No. 503 (1829); Caixa 1130 - No. 9306 (1833); Caixa 912 - No. 2590 (1834); Maço 6848 - No. 3305 (1846); e Caixa 4017 No. 492 (1849).

Ewbank-Op. cit., Volume I,p. 179.

${ }^{12}$ Luccock, John - Notas sobre o Rio de Janeiro e as Partes Meridionais do Brasil. Primeira edição de 1820.Tradução de Milton da Silva Rodrigues. Belo Horizonte — São Paulo, Editora Itatiaia — EDUSP, 1975, p. 72. 
segunda senhora era Maria Ignacia de Negreiros Macedo que teve sua escrava Ermelinda presa e também recolhida ao Depósito Público por jogar na rua uma vasilha de água suja. As duas senhoras apresentaram requerimentos à Câmara acentuando sua condição de pobres para obterem a soltura das cativas e a isenção do pagamento das multas impostas, a segunda delas inclusive enfatizando sua situação de "casada e carregada de filhos, tendo seu marido fora em serviço público". Evidentemente, a ausência das cativas acarretou às duas senhoras, pelo menos temporariamente, a perda das suas fontes de sustento. ${ }^{13}$

Os ex-escravos também estavam entre os senhores pobres possuidores de um ou dois cativos. Obviamente, seu número não era grande, pois os mecanismos de alforria eram muito limitados. Além disso, nem todos os que conseguiam a alforria tinham condições financeiras para a compra de cativos. Entretanto, alguns poucos libertos, com os rendimentos do seu trabalho, conseguiram formar um certo pecúlio e o investiram na compra de escravos que colocavam a seu serviço, no ganho de rua, ou então alugavam a terceiros. Desse modo, estes libertos procuravam seguir o exemplo dado por seus antigos senhores, reproduzindo com os cativos adquiridos as mesmas relações de exploração e autoridade em que estiveram envolvidos anteriormente.

Outros indivíduos já viviam mais confortavelmente, possuindo de seis a dez escravos, e ocupavam uma posição mais elevada na hierarquia social da época, embora ainda estivessem distantes daqueles considerados ricos e detentores de prestígio. Este era o caso de 42 inventariados de nossa amostragem, que se encontravam entre os "setores médios" da primeira metade do século XIX. Alguns desses indivíduos desempenhavam atividades profissionais mais respeitadas (profissão liberal, oficial militar, religioso, comerciante, etc), mas a grande maioria deles vivia de rendimentos do aluguel ou ganho dos escravos, não sendo poucos aqueles que completavam os seus rendimentos com os aluguéis de imóveis. (Ver Tabela II).

Uma das cenas mais interessantes, narrada e desenhada por JeanBaptiste Debret, é aquela que mostra um funcionário do governo saindo a passeio com sua família, nos anos 1820 presumivelmente. Debret enfatizava que este funcionário era um homem de "fortuna média" e pela descrição do séquito que o acompanhava, além da esposa e filhos,

Arquivo Geral da Cidade do Rio de Janeiro - Escravos ao Ganho e Escravidão: 1842-1846. Códice-6-1-45. 
podemos notar a presença de seis escravos. Segundo Debret, um outro escravo cozinheiro não acompanhava o cortejo porque era o guarda da casa. Pela descrição do pintor francês, este funcionário público - proprietário de sete escravos — era um exemplo típico daqueles homens de situação financeira e posição social intermediárias, seguindo inclusive os "rituais" de aparição pública compartilhados pelos setores médios da época. ${ }^{14}$

Não muito distantes da situação narrada por Debret estavam os inventariados Antônio Moreira dos Santos, Manoel Soares Rego e o Padre José Maria de São Tiago. O primeiro deles, Antônio Moreira dos Santos, falecido em 1831, possuía duas casas no centro da cidade, duas casas no caminho da Tijuca, um terreno no Andaraí, alguns objetos de ouro e prata e nove escravos. O segundo, Manoel Soares Rego, falecido em 1838, possuía uma chácara no Engenho Novo, com lavoura de café, um cavalo e seis escravos, enquanto que o Padre José Maria de São Tiago, falecido em 1844, dos três inventariados era o que vivia mais confortavelmente, possuindo quatro casas na Rua do Propósito (no centro da cidade), diversos objetos de ouro e prata e dez escravos. ${ }^{15}$

Os setores mais abastados, com prestígio e influência política, eram aqueles formados por indivíduos que possuíam muito acima de dez escravos. Entre estes setores, encontramos indivíduos que formavam uma espécie de "camada média superior" e viviam confortavelmente em chácaras ou casas assobradadas, sustentados por salários ou ganhos profissionais elevados, como era o caso de oficiais militares de altas patentes, funcionários públicos dos mais altos escalões ou bem sucedidos profissionais liberais, ou então por rendimentos de alguma empresa de porte médio (comércio, indústria ou lavoura), de aluguéis de diversos imóveis, de um bom número de apólices e ações (o que era menos freqüente) e da exploração do aluguel ou ganho de uma boa parcela de seus escravos. O número de escravos que geralmente possuíam variava de onze a vinte, tal como acontecia com 28 inventariados de nossa amostragem que podiam ser classificados como membros desta "camada média superior". Os indivíduos mais ricos, de maior prestígio e

${ }^{14}$ Debret,Jean-Baptiste - Viagem Pitoresca e Histórica ao Brasil,Tomo I. Primeira edição de 1835-1839.Tradução de Sérgio Milliet.São Paulo, Livraria Martins Editrora, 1954, pp. 126-127.

ANRJ - Inventários "post-mortem": Maço 7716 - No. 8375 (1831); Maço $374-$ No. 6604 (1838); e Caixa 5456 - No. 415 (1844). 
influência, que nutriam grandes aspirações pelos títulos e honrarias concedidos pelo Estado Imperial, eram aqueles que, além de grandes negócios comerciais, muitos imóveis urbanos, fazendas, terras e lavouras nas cercanias da cidade, possuíam muito acima de vinte escravos, uma boa parte deles residindo com suas famílias em extensas e "paradisíacas" chácaras de Botafogo, Catete, Laranjeiras e Engenho Velho. Entre estes mais ricos, podemos encontrar apenas quinze inventariados da nossa amostragem. (Ver Tabela II).

As relações de bens de alguns inventariados nos dão uma clara idéia acerca dos níveis de riqueza dos setores mais abastados, Comecemos pelos indivíduos da "camada média superior". Cândida Rosa da Piedade, falecida em 1832, deixou para seus herdeiros uma casa de sobrado com grande loja comercial no andar térreo, localizada na Rua do Sabão, muitas jóias e objetos de ouro e prata, um aparelho de chá de porcelana, valiosos móveis, mercadorias da sua loja e catorze escravos. O Tenente-Coronel do Exército, Florêncio Antônio dos Santos, falecido em 1834, deixou para seus herdeiros nove casas no centro da cidade, quatro carruagens, dois botes, diversos objetos de ouro e prata, algumas apólices, seis bestas e dezoito escravos.Já Antônio Francisco de Barros, ao falecer em 1849, deixou para seus herdeiros diversos terrenos na Estrada Engenho Novo-Jacarepaguá, quatro casas no mesmo local (dois grandes de sítio e dois menores de pau-a-pique), uma casa de sobrado na Rua do Cemitério da Gambôa, cinco casas térreas em diversos pontos do centro da cidade e treze escravos. ${ }^{16}$

Entre os mais ricos, encontramos dois fazendeiros e um grande comerciante inventariados. O primeiro fazendeiro era o Sargento-Mor do Exército, Manoel Gomes Cardoso, falecido em 1814, que deixou para seus herdeiros duas grandes casas na Rua Larga de São Joaquim, uma fazenda nas cercanias da cidade, denominada "Anhangá", com diversas casas de vivenda, senzalas, plantações de café, frutas e mandioca, grandes extensões de terra no Campo de Saracuruna, muitos objetos de ouro e prata, 17 bestas, 16 bois e vacas, 16 carneiros e 108 escravos. O comerciante João José de Mello, falecido em 1825, deixou para seus herdeiros uma grande casa assobradada na Rua Larga de São Joaquim, nove casas menores na mesma rua, uma casa na Estrada da Tijuca, uma grande chácara no Engenho Novo, dois pequenos carros, duas carroças,

${ }^{16}$ Ibidem: Caixa 4060 - No.732 (1832); Caixa 3615 - No.7 (1834); : Maço 419 No. 7992 (1849). 
um barco, 5:000\$000 réis em dinheiro e 96 escravos. O segundo fazendeiro, Domingos Lopes da Silva Araújo, era também alto funcionário público e devia ser um dos homens de maior fortuna no Rio de Janeiro. Ao falecer em 1849, Domingos Lopes da Silva Araújo deixou para seus herdeiros um sítio denominado "Boqueirão", localizado em Campo Grande, com casa de vivenda, nove senzalas, plantações de café, canade-açúcar e frutas, e uma grande fazenda denominada "Retiro", também em Campo Grande, com casa de vivenda, um engenho de fazer farinha de mandioca, um engenho de beneficiar cana-de-açúcar, plantações de cana e mandioca e 56 senzalas. Este funcionário públicofazendeiro era também possuidor de alguns objetos de ouro e prata, 520 cabeças de gado (seis cavalos, 35 bestas, 299 bois e vacas e 180 carneiros) e 229 escravos. Destes escravos, catorze eram mantidos na cidade, nos seus serviços pessoais. ${ }^{17}$

Com relação aos investimentos de capital, as relações de bens dos inventariados consultados indicam claramente que, na primeira metade do século XIX, tanto para os mais ricos como para os mais pobres, escravos e imóveis constituíram-se nas formas de investimento predominantes, pois eram as únicas que ofereciam mais segurança para a aplicação de capital no limitado quadro de alternativas econômicas que a cidade e o País apresentavam, na época. A aquisição de escravos foi a única forma de investimento realizada por 43 inventariados (21,5\%), enquanto que 16 deles ( $8 \%$ ) possuíam apenas imóveis. Já a grande maioria dos inventariados, 112 indivíduos (56\%), achou mais conveniente investir o seu dinheiro, a mesmo tempo, na compra de escravos e imóveis. Apenas dez inventariados (5\%) procuraram aplicar o seu dinheiro, além de escravos e imóveis, em apólices da dívida pública do Estado, ações de algumas poucas empresas e cadernetas de poupança bancária, que lhes possibilitavam rendimentos proporcionais ao capital investido. Finalmente, encontramos 19 inventariados $(9,5 \%)$ que possuíam apenas pequenas somas de dinheiro ou bens de pouco valor, tais como alguns objetos de ouro e prata,jóias ordinárias, velhos e estragados móveis, alguns animais de transporte, pequenos veículos ou pequenas embarcações. (Ver Tabela III).

A abolição do tráfico de escravos africanos, em 1850 , veio alterar os padrões de propriedade escrava que vigoravam no Rio de Janeiro. Com

Ibidem: Maço 459 - No. 8640 (1814); Caixa 3891 - No. 2846 (1825); e Caixa 4083 - No. 951 (1849). 
Tabela III. Bens possuídos pelos inventariados nos 200 inventários "post-mortem" consultados para os anos 1810-1849.

\begin{tabular}{|c|c|c|c|c|c|}
\hline . & $\begin{array}{c}1810 \\
- \\
1819\end{array}$ & $\begin{array}{c}1820 \\
- \\
1829\end{array}$ & $\begin{array}{c}1830 \\
- \\
1839 \\
\end{array}$ & $\begin{array}{c}1840 \\
- \\
1849\end{array}$ & Total \\
\hline Escravos & 12 & 9 & 12 & 10 & 43 \\
\hline Escravos e Terras & 32 & 29 & 26 & 25 & 112 \\
\hline Escravos e Açōes & - & 1 & - & 1 & 2 \\
\hline Escravos e Apólices & - & - & - & 1 & 1 \\
\hline Escravos, Terras e Ações & - & - & 1 & 1 & 2 \\
\hline Escravos, Terras c Apólices & - & - & 2 & - & 2 \\
\hline Escravos, Cadernetas de Poupança e Apólices & - & - & - & 1 & 1 \\
\hline Escravos, Cadcrnetas de Poupança, Açōes e Ap & Slices - & - & 1 & - & 1 \\
\hline Escravos, Cadernetas de Poupança, Terras e Ap & lices - & - & - & 1 & 1 \\
\hline Terras & 2 & 4 & 3 & 7 & 16 \\
\hline Berns de Pequeno Valor * & 4 & 7 & 5 & 3 & 19 \\
\hline Total & 50 & 50 & 50 & 50 & 200 \\
\hline
\end{tabular}

FONTE: A NR J - Inventários Op. cit., $1810-1849$.

* Entre os bens de pequeno valor, podem ser incluídos alguns objetos de ouro e prata, bijuterias, móveis velhos, animais de carga (cavalos, burros e mulas), pequenos veículos, botes e, até mesmo, pequenas somas de dinheiro.

o fim do tráfico africano, deu-se a intensificação do tráfico interno e os grandes cafeicultores doVale do Paraíba lançaram-se sobre a população cativa da cidade. Isto determinou uma enorme elevação nos preços de escravos e os senhores da cidade, não resistindo a esta elevação, acharam muito mais lucrativo vendê-los para as áreas cafeeiras. Por outro lado, os senhores só se desfizeram de seus escravos porque encontraram na diversificação da economia do Rio de Janeiro, a partir dos anos 1850 , alternativas mais interessantes para investimento do seu capital, o que fez com que a aquisição e a posse do elemento cativo deixasse de ser considerada, por muitas pessoas, como uma forma de investimento rentável e segura. Muitos senhores desfizeram-se de todos os seus escravos, principalmente aqueles mais pobres. Outros conservaram ainda um certo número deles para as suas atividades domésticas ou para alugá-los ou exploraram o seu ganho.

O dinheiro obtido com a venda dos escravos passou a ser aplicado na compra de imóveis urbanos, que se valorizaram em virtude do crescimento populacional da cidade e da crise de moradia de meados do século XIX, e também em cadernetas de poupança bancária, apólices ou obrigações da dívida pública do Estado, que passaram a oferecer rendimentos bem mais vantajosos, e na aquisição de ações das empresas 
comerciais, bancárias ou de serviços urbanos, que surgiram na "febre" dos grandes empreendimentos que assolou a cidade a partir dos anos $1850 .{ }^{18}$ Além disso, desfazendo-se de seus escravos, os habitantes do Rio de Janeiro podiam dispor para os trabalhos domésticos, e demais atividades, da mão-de-obra barata fornecida pelas grandes levas de imigrantes portugueses que chegavam continuamente à cidade. Assim, esses indivíduos, com os rendimentos oriundos da especulação financeira e dos aluguéis de valorizadíssimos imóveis urbanos, puderam continuar a vida tranqüila e o ócio a que estavam acostumados.Transformaram-se nos famosos "capitalistas" da segunda metade do século XIX, tal como Rubião, Cristiano Palha, Agostinho Santos e tantos outros personagens que povoaram a obra de Machado de Assis. ${ }^{\prime \prime}$

Até mesmo aqueles senhores que quiseram manter seus cativos encontraram na diversificação da economia do Rio de Janeiro meios para tornar a propriedade escrava menos arriscada. Com o surgimento de muitas companhias seguradores nesta "febre" de empreendimentos, muitos senhores passaram a fazer seguro de seus escravos, temendo acidentes

A historiadora Kátia de Queirós Mattoso também constatou, baseada em amostragem com inventários post-mortem, que o mesmo fenômeno se deu em Salvador. A partir de 1850, não só houve uma redução do número de escravos nas relações de bens dos inventariados da amostragem, como também se verificou um aumento de seus bens imobiliários urbanos e um a considerável inversão de capital em ações bancárias e obrigações da dívida pública. (Mattoso - Ser escravo no Brasil. São Paulo, Editora Brasiliense, 1982, pp. 74-76).

" Machado de Assis, Joaquim Maria - Quincas Borba. Primeira edição de 1891. Rio de Janeiro - São Paulo, W. M. Jackson Inc,, Editores, 1946, p. 7; e Esaú e Jacó. Primeira edição de 1904. São Paulo,Editora Ática, 1975,p. 16. A grande redução da população cativa do Rio de Janeiro (e das demais cidades brasileiras), entre os anos 1850 e 1870 , tornou-se um importante fator de enfraquecimento da instituição da escravidão no ambiente urbano. No Rio de Janeiro, as novas alternativas para investimento de capital e a possibilidade de reposição da mão-de-obra através da imigração (principalmente a portuguesa) geraram um crescente desinteresse da população livre pela escravidão, o que, por sua vez, transformou-se no "pano de fundo" para a ação do movimento abolicionista nos anos 1880. O Abolicionismo encontrou, na cidade, um fértil campo para sua disseminação, sobretudo entre os setores sociais mais abastados que já não viam a mão-de-obra cativa como o fundamento da economia e do poder político-social do país. Sobre isso, ver: Luiz Carlos Soares — "Masters and slaves in nineteenth-century Rio de Janeiro" (Capítulo III) e"The end of slavery in Rio de Janeiro" (Conclusão), em Urban Slavery in Nineteenthcentury Rio de Janeiro. Londres, Tese de doutorado apresentada no University College London (Universidade de Londres), 1988, respectivamente pp. 94-144 e 448-451. 
ou doenças que os deixassem inválidos ou os matassem precocemente, sem contar as fugas freqüentes.Tal precaução tomou o Capitão do Exército, Miguel Antônio Pastana, que, ao falecer em 1859, deixou como herança para seus filhos cinco escravos, todos com seguro. ${ }^{20}$ Um anúncio publicado no Jornal do Commercio, em 1860, revelava também a precaução de um senhor que vendia um escravo muito habilidoso:

"Vende-se um preto bonito, peça de 22 anos de idade e reforçado, é insigne lavadeiro e engomadeiro, tanto de roupa de homem como de senhora, perfeito cozinheiro de forno e fogão, bom cocheiro e costureiro, e está segurado na Companhia Previdência, na rua da Misericórdia n. 7. Dá-se a contento ajustando-se". ${ }^{2}$

Um outro senhor da Rua dos Ourives, 136, também interessado em vender uma escrava sua com diversas habilidades, segurou-a não só contra o risco de morte, como também contra a possibilidade da cativa comprar a sua alforria ou de ser declarada a abolição total da escravatura no país. É isto que nos mostra um anúncio doJornal do Commercio de 1880, que talvez refletisse os temores do referido senhor diante dos grandes debates que se travavam no parlamento e na sociedade acerca do fim do cativeiro:

"Vende-se uma parda escura de 30 anos de idade, insigne cozinheira de forno e fogão, e massas, perfeita engomadeira de toda a qualidade de roupas de homem e senhora, lava, coze e trata com ornamentação e asseio de uma casa; não tem vícios, é cuidadosa com crianças e está segurada por 1:800\$000 pelo tempo de 5 anos contra o risco de morte e alforria; o motivo da venda satisfaz e só se vende para casa particular". ${ }^{22}$

Uma outra amostragem com duzentos inventários post-mortem, relativos ao período 1850-1888, indica-nos claramente as mudanças nos padrões da propriedade escrava e, de certo modo, nos critérios de estratificação social no Rio de Janeiro, na segunda metade do século XIX. Seguimos os mesmos procedimentos adotados na amostragem relativa

ANRJ - Inventário "post-mortem": Caixa 3617 - No. 126 (1859).

Jornal do Commercio (doravante citado comJC). Rio de Janeiro, 04/06/1860.

Ibidem. 17/08/1880. 
à primeira metade do século, consultando cinqüenta inventários por década e conservando os mesmos números de inventários de homens e mulheres - trinta e vinte respectivamente - , pois neste período não chegou a haver uma grande mudança na proporção sexual da população livre do Rio de Janeiro (ver Tabela I). Temos, assim, para todo o período 120 inventários de homens e oitenta de mulheres.

Dos duzentos inventariados desta segunda amostragem, o número daqueles que não possuíam escravos é consideravelmente superior ao da primeira amostragem, chegando ele a 96 e correspondendo a $48 \%$ dos inventariados. Para sessenta deles, foi possível identificar as ocupações, enquanto que para 36 não existem indicações sobre seus meios de vida (ver Tabela IV). Isto pode significar que estes 36 inventariados eram indivíduos extremamente pobres, pois, inclusive, nas suas relações de bens constavam apenas pequenas quantias de dinheiro, móveis velhos ou sem muito valor, jóias ordinárias, alguns objetos de ouro e prata e outros objetos de pouco valor. Este número de inventariados sem ocupação é $50 \%$ superior ao número de inventariados nesta situação da primeira amostragem (24 inventariados) e este aumento pode refletir o crescimento do nível de pauperização da população livre da cidade, com a chegada de muitos trabalhadores imigrantes e a proletarização potencial daqueles setores pobres que, vivendo anteriormente sustentados por um, dois ou mais escravos, desfizeram-se deles e não souberam aplicar apropriadamente o dinheiro arrecadado com sua venda, ou então este dinheiro não foi suficiente para sustentá-los a longo prazo. Convém frisar que houve sucessivos aumentos no custo de vida na segunda metade do século XIX, devido sobretudo às freqüentes elevações nos preços dos gêneros alimentícios, roupas e moradia, e a população, para viver condignamente, passou a necessitar de rendimentos be m superiores àqueles da primeira metade do século. Possivelmente, o dinheiro que muitos arrecadaram, com a venda de seus poucos cativos, foi rapidamente devorado pela elevação do custo de vida.

Sobre o aumento do custo de vida e a carestia dos gêneros alimentícios a partir dos anos 1850, ver: Soares, Sebastião Ferreira - Notas Estatísticas sobre a Producção Agricola e Carestia dos Generos Alimenticios no Imperio do Brazil. Rio de Janeiro,Typographia Imperial e Constitucional de J.Villeneuve, 1860, pp. 129-139; Lobo, Eulália Maria Lahmeyer - História do Rio deJaneiro (do capital comercial ao capital industrial e financeiro), Volume I. Rio de Janeiro, IBMEC, 1978, pp. 232-235; e Linhares, Maria Yedda Leite - História do Abastecimento: uma problemática em questão (1530-1918). Brasília, B 1NAGRI, 1979, pp. 174-190. 
Os outros sessenta inventariados tinham as mais diversas ocupações, encontrando-se entre eles comerciantes, industriais, senhorios, "capitalistas", profissionais liberais, oficiais militares, religiosos, funcionários públicos e pessoas com profissões mais humildes, tais como boticários, artesãos, operários e caixeiros. A presença destas duas últimas categorias profissionais entre os inventariados pode refletir, inclusive, o crescimento do exército de trabalhadores assalariados na cidade. (Ver Tabela IV).

As relações de bens de quatro inventariados nos fornecem uma clara idéia das diferenças de situação financeira e posição social que existiam entre estes inventariados sem escravos. A primeira relação de bens é a do advogado e comerciante José Rodrigues Ferreira, falecido em 1866 , que deixou para seus herdeiros catorze casas na Rua da Saúde, um trapiche na mesma rua, uma casa na Rua do Propósito e 35 apólices da dívida pública. A outra relação de bens é a de um bem situado artesão, Antônio Francisco dos Santos, falecido em 1875, que deixou para seus herdeiros uma casa na Rua d'Assunção e 19 apólices da dívida pública. Já na relação de bens do mulato Irineu da Paixão Almeida, falecido em 1880 e sem nenhum herdeiro, constavam apenas duas ações da Sociedade de Comércio da Bahia pouco valiosas. Praticamente, na mesma situação se encontrava o operário português Manoel da Costa Campos, falecido em 1885 e também sem nenhum herdeiro, que possuía apenas uma caderneta da Caixa Econômica no valor de $250 \$ 000$ réis. ${ }^{24}$

Os 104 inventariados possuidores de escravos representam $52 \%$ do total de inventariados da segunda amostragem e seu número é bem inferior ao dos inventariados escravistas da primeira amostragem. Na segunda amostragem, aparecem 22 inventariados que viviam exclusivamente da sua ocupação profissional, empregando seus cativos em serviços domésticos ou nas atividades que exerciam, podendo alugá-los ou colocá-los ao ganho esporadicamente. Seu número corresponde a menos da metade dos inventariados na mesma situação da primeira amostragem. Entre estes 22 indivíduos encontravam-se industriais, comerciantes, profissionais liberais, oficiais militares, religiosos, lavradores e um boticário. Já oito inventariados, além das suas ocupações profissionais, viviam também de aluguéis de imóveis (sete deles) e rendimentos de capital (um apenas). (Ver Tabela IV).

Outros 63 inventariados não exerciam nenhuma atividade profissio-

${ }^{24}$ ANRJ - Inventários "post-mortem":Maço 14 - No. 16 (1866);Caixa 3995 - No. 107 (1875); Caixa 42.32 - No. 1453 (1880); e Maço 391 - No. 7027 (1885). 
Tabela IV. Distribuição da propriedade escrava nos inventários consultados, de acordo com as ocupações dos inventariados: 1850-1888.

\begin{tabular}{|c|c|c|c|c|c|c|c|c|c|c|c|}
\hline & 0 & $\begin{array}{l}1 \\
- \\
2\end{array}$ & $\begin{array}{l}3 \\
- \\
5\end{array}$ & $\begin{array}{c}6 \\
- \\
10 \\
\end{array}$ & $\begin{array}{c}11 \\
- \\
20\end{array}$ & $\begin{array}{c}21 \\
- \\
30\end{array}$ & $\begin{array}{c}31 \\
- \\
40\end{array}$ & $\begin{array}{c}41 \\
- \\
50\end{array}$ & $\begin{array}{c}51 \\
- \\
100\end{array}$ & $\begin{array}{r}100 \\
+ \\
\end{array}$ & \\
\hline \multicolumn{12}{|c|}{ Viriam dos Rendimentos Profissionais } \\
\hline Comerciantes & 1 & 2 & - & - & 1 & - & - & - & - & - & 4 \\
\hline Comerciantes/Lavrudores & - & - & - & - & - & 1 & - & - & - & - & 1 \\
\hline lindustriais & 1 & 3 & - & - & - & - & - & - & - & - & 4 \\
\hline Advogados & - & - & 2 & - & .. & - & - & - & - & - & 2 \\
\hline Médicos & - & - & - & 1 & - & - & - & - & - & - & 1 \\
\hline Professores & - & 1 & - & - & - & - & - & - & - & - & 1 \\
\hline Oficiais Militures & - & 1 & 2 & - & - & - & - & - & - & - & 3 \\
\hline Religiosos & 1 & 1 & - & - & - & - & - & - & - & - & 2 \\
\hline Religiosas/Comerciantes & - & - & - & 1 & - & - & - & - & - & - & 1 \\
\hline Funcionários Páblicos & 1 & - & - & - & - & - & - & - & - & - & 1 \\
\hline Lavradores & - & 2 & - & - & 2 & - & 1 & - & - & - & 5 \\
\hline Boticários & 1 & - & 1 & - & - & - & - & - & - & - & 2 \\
\hline Artesãos & 2 & - & - & - & - & - & - & - & - & - & 2 \\
\hline Operários & 2 & - & - & - & - & - & - & - & - & - & 2 \\
\hline Caixeiros & 1 & - & - & - & - & - & - & $\therefore$ & - & - & 1 \\
\hline Total & 10 & 10 & 5 & 2 & 3 & 1 & 1 & - & - & - & 32 \\
\hline
\end{tabular}

Viviam dos Rendimentos Profissionais, Alnguèis de

Imóveis e/ou Dividendos de Capital Fazendeiros/

Senhorios

Lavradores/Senhorios

Comerciantes/Senhorios

Oficiais Militares/Comer- ciantes/Senhorios

Funcionirios Públicos/Sentrorios

Comerciances/Capitalistas

Religiosos/Capitalistas

Comerciantes/Senhorios/Capitalistas

Advogidos/Senhorios/Capitalistas

Oficinis Militares/Seuho-rios/Capitalistas

\begin{tabular}{llllllllllll}
\hline Total & 6 & 3 & 2 & - & 1 & 1 & - & - & 1 & - & 14 \\
\hline Viviam Exclusivamente dos Rendimentos de Escravos & - & 4 & 7 & + & 1 & - & - & - & - & - & 16 \\
Total & - & 4 & 7 & 4 & 1 & - & - & - & - & - & 16
\end{tabular}

Total

Viviatn dos Rendimentos de Escravos, Alugucis de

Imóteis elou Dividendos de Capital Exploradores

dos Rendimentos de Escravos/Senhorios

Exploradores dos Rendi- mentos de Escravos/

Capitalistas

Exploradores dos Rendi- mentos de Escravos/

Senhorios/Capitalistas

\begin{tabular}{|c|c|c|c|c|c|c|c|c|c|c|c|}
\hline Total & - & 3 & 4 & 7 & 8 & 2 & - & - & - & - & 24 \\
\hline
\end{tabular}

Viviam dos Rendimentos de Aluguéis de Imóveis

$\begin{array}{lllllllllll}\text { clou Dividendos de Capital Senhorios } & 21 & 3 & 3 & 5 & - & - & - & - & - & -\end{array}$

Capitalistas

Scthorios/Capitalistas

Total

Sem Ocupaçāo Delarada

\begin{tabular}{|c|c|c|c|c|c|c|c|c|c|c|c|}
\hline Total & 36 & 7 & 4 & - & - & - & - & - & - & - & 47 \\
\hline Total Geral & 96 & 34 & 27 & 24 & 13 & 4 & 1 & - & 1 & - & 200 \\
\hline
\end{tabular}

FONTE:ANR] - Ime'thirios "Post-Wort'w". Para os Anos 1850-1888. 
nal, mas tinham seu sustento (e de seus familiares) garantido por rendimentos oriundos da exploração do aluguel ou ganho de escravos, aluguéis de imóveis e dividendos de apólices e ações. Os inventariados que viviam exclusivamente do aluguel ou ganho de cativos chegavam a 16, número este que corresponde a menos da metade dos indivíduos desta categoria que aparecem na primeira amostragem. Bem inferior é também o número de inventariados que, além de explorarem seus cativos nestas duas modalidades, viviam dos rendimentos de aluguéis de imóveis, chegando a dez indivíduos. Já os que exploravam o aluguel ou ganho de cativos e ainda possuíam rendimentos de capital - nove inventariados - dobraram em comparação com os da primeira amostragem. Um aumento também se verificou no número daqueles inventariados - cinco ao todo - que preferiram combinar as três formas de obtenção de renda mencionadas. O número daqueles que preferiram conservar seus escravos unicamente nas atividades domesticas e obter seu sustento com rendimentos de capital e aluguéis de imóveis também é bem superior - 23 inventariados - e corresponde ao triplo dos da primeira amostragem. Assim, temos onze inventariados que tinham sua fonte de sustento nos aluguéis de imóveis, oito que viviam de rendimentos de capital e outros quatro que combinavam as duas formas de obtenção de renda. (Ver Tabela IV).

Entre os inventariados possuidores de escravos também estavam onze indivíduos sem ocupação identificada, mas que provavelmente viviam da exploração do aluguel ou ganho dos seus cativos (verTabela IV).Todavia, seu número corresponde aproximadamente à terça parte dos indivíduos desta categoria na primeira amostragem, o que significa trata-se de mais um reflexo da redução do número de senhores que tinham seu sustento única e exclusivamente no aluguel ou ganho de escravos.

O estudo quantitativo realizado com as duas amostragens de inventários post-mortem, embora possa parecer enfadonho e desnecessário para muitos, constituiu-se num esforço bastante útil e revelador neste nosso trabalho, indicando não só a existência de diferentes padrões da propriedade escrava da primeira para a segunda metade do século XIX, como também uma mudança considerável nas formas de investimento realizadas pelos diversos setores da população de um período para outro. Se na amostragem relativa à primeira metade do século, apenas 49 inventariados $(24,5 \%$ do total) investiram em imóveis e, em menor escala, na aquisição de apólices e ações, na amostragem da segunda metade do século, o número dos que preferiram estas formas de investimento aumentou consideravelmente, chegando a 105 e correspon- 
dendo a 52,5 \% do total de inventariados (ver Tabela V). Esta diversificação de investimentos não refletiu apenas a diversificação das atividades econômicas do Rio de Janeiro a partir dos anos 1850 , mas também indicou, em termos mais amplos, as mudanças na economia escravista a partir da abolição do tráfico negreiro africano.

Tabela V. Bens possuídos pelos inventariados nos 200 inventários "post-mortem" consultados para os anos 1850-1888.

\begin{tabular}{|c|c|c|c|c|c|}
\hline \multirow[t]{3}{*}{ Bens possuídos } & \multicolumn{5}{|c|}{ Número de Inventariados } \\
\hline & 1810 & 1820 & 1830 & 1840 & \\
\hline & 1819 & 1829 & 1839 & 1849 & Total \\
\hline Escravos & 8 & 5 & 9 & 1 & 23 \\
\hline Escravos e Terras & 26 & 11 & 8 & 8 & 53 \\
\hline Escravos e Cadernetas de Poupança & - & 2 & - & - & 2 \\
\hline Escravos e Ações & 1 & 1 & - & - & 2 \\
\hline Escravos e Apólices & 2 & 3 & 1 & 1 & 7 \\
\hline Escravos, Ações e Apólices & 1 & - & - & - & 1 \\
\hline Escravos, Terras e Ações & 1 & - & 2 & 1 & 4 \\
\hline Escravos, Terras e Apólices & 2 & 3 & 2 & - & 7 \\
\hline Escravos, Cadernetas de Poupança e Ações & - & - & - & 1 & 1 \\
\hline Escravos, Cadernetas de Poupança, Terras e Ações & 1 & - & 1 & - & 2 \\
\hline Terras & 6 & 10 & 8 & 13 & 37 \\
\hline Terras e Cadernetas de Poupança & - & 2 & 1 & - & 3 \\
\hline Terras e Ações & - & 1 & - & 2 & 3 \\
\hline Terras e Apólices & - & 2 & 4 & 2 & 8 \\
\hline Terras, Ações e Apólices & - & - & 1 & - & 1 \\
\hline Terras, Cadernetas de Poupança e Apólices & - & - & 1 & - & 1 \\
\hline Terras, Cadernetas de Poupança, Ações e Apólices & - & - & - & 1 & 1 \\
\hline Cadernetas de Poupança & - & - & 2 & 1 & 3 \\
\hline Cadernetas de Poupança e Apólices & & - & - & 1 & 1 \\
\hline Ações & - & - & 1 & 3 & 4 \\
\hline Apólices & 1 & 1 & 2 & 3 & 7 \\
\hline Ações e Apólices & - & 1 & - & 1 & 2 \\
\hline Bens de Pequeno Valor * & 1 & 7 & 7 & 1 & 26 \\
\hline Total & 50 & 50 & 50 & 50 & 200 \\
\hline
\end{tabular}

FONTE: ANR J - Inventários Op. cit., $1850-1888$.

* Entre os bens de pequeno valor, podem ser incluídos alguns objetos de ouro e prata, bijuterias, móveis velhos, animais de carga (cavalos, burros e mulas), pequenos veículos, botes e, até mesmo, pequenas somas de dinheiro.

Sem a tradicional fonte de reposição africana e com a gigantesca elevação de seus preços, os investimentos em escravos deixaram de ser tão seguros como na primeira metade do século XIX, e não foi por mero luxo que alguns senhores procuraram fazer seguro de seus cativos nas diversas seguradoras criadas no Rio de Janeiro. Tanto para os habi- 
tantes ricos da cidade, como para os remediados e pobres que possuíam algum capital para investir (muitas vezes oriundo da venda de seus cativos para as áreas cafeeiras), os imóveis, as apólices, as cadernetas de poupança bancária e as ações de empresas se constituíram nas formas de investimento que ofereciam mais segurança para o retorno do capital. Isso impulsionou uma série de mudanças na economia da cidade, que começou a adotar em maior escala as práticas capitalistas.

Por outro lado, ria segunda metade do século XIX, a propriedade escrava e o número de escravos possuídos deixaram de ser os principais indicadores da posição social e de prestígio entre os habitantes do Rio de Janeiro. A situação financeira dos indivíduos em primeiro lugar, e sua importância profissional, logo em seguida, passaram a ser os principais indicadores da sua posição na hierarquia social. A posse de escravos ainda continuou como fator de atribuição de status, mas tornou-se cada vez menos importante com a proximidade da abolição da escravatura. O universo dos personagens de Machado de Assis refletia muito bem a mudança nos critérios de atribuição de importância social aos indivíduos. É célebre uma passagem inicial de Quincas Borba em que o enriquecido Rubião, numa manhã, àjanela de sua bela casa de Botafogo, fitando a enseada, "cotejava o passado com o presente", admirandose de sua rápida ascensão de professor do interior de Minas a "capitalista", residente num dos mais belos lugares do Rio de Janeiro, o que só foi possível pelo fato deste personagem ter herdado, como "herdeiro universal", toda a fortuna do seu amigo filósofo Quincas Borba. ${ }^{25}$

Todavia, ainda permanecia na mentalidade da população, sobretudo entre os setores médios e mais abastados, a velha aversão aos trabalhos manuais. Mas, o discurso de negação ao trabalho apresentava modificações em relação à primeira metade do século XIX, refletindo as mudanças sociais verificadas. Se antes, o trabalho era "coisa" exclusiva de negros cativos, a partir dos anos 1850, com a chegada maciça dos imigrantes europeus, o trabalho também passou a ser "coisa" dessa gente. Um viajante holandês, Josef van Halle, percebeu muito bem esta mudança na ideologia do trabalho, ao viajar pelo Rio de Janeiro e províncias vizinhas em 1876. O viajante relatava:

"Quantas vezes não tenho eu ouvido nas minhas viagens, moços ricos e mesmo pobres, exprimirem-se a respeito do trabalho dizen-

Machado de Assis - Quincas Borba. Op. cit., p. 7. 
do: o trabalho é feito para os burros, os escravos e as pessoas grosseiras da sociedade vindas de Portugal. Açores e outros lugares da Europa para servir-nos e para o que são bem pagas". ${ }^{26}$

Uma outra passagem de Machado de Assis, no mesmo Quincas Bor$b a$, mostra-nos claramente a atitude de alguns indivíduos mais ricos com relação à necessidade de substituição do trabalho escravo pelo trabalho livre nos serviços domésticos, principalmente porque entre os setores abastados, com uma pretensa mentalidade modernizante, a ostentação de "criados brancos" passou a ser indicador de riqueza e prestígio social. O ainda tradicionalista e interiorano Rubião foi pressionado pelo recente amigo Cristiano Palha (conhecedor das novas formas de comportamento e costumes) a afastar seus escravos dos serviços domésticos. Não é demais reproduzir a interessante passagem machadiana:

"O criado esperava teso e sério. Era espanhol; e não foi sem resistência que Rubião o aceitou das mãos de Cristiano; por mais que lhe dissesse que estava acostumado aos seus crioulos de Minas, e não queria línguas estrangeiras em casa, o amigo Palha insistiu, demostrando-lhe a necessidade de ter criados brancos. Rubião cedeu com pena. O seu bom pajem, que ele queria pôr na sala, como um pedaço da província, nem o pode deixar na cozinha, onde reinava um francês, Jean; foi degradado a outros serviços". ${ }^{27}$

Se quisermos estabelecer a média de escravos possuídos por cada um dos duzentos inventariados da nossa segunda amostragem, esta será de 3,49 para todo o período (1850-1888), o que corresponde a menos da metade da média geral da primeira amostragem. Entretanto, serão as médias decenais que nos darão uma melhor idéia da redução de escravos possuídos pelos inventariados, não se esquecendo de que foi mantido o número de cinqüenta inventários por década e que a média de 1840-1849 é 11,08 escravos por cada inventariado. Desse modo, dos 319 escravos avaliados nos inventários de 1850-1859, teremos uma média de 6,38 escravos por cada inventariado, que corresponderá a $57,58 \%$

\footnotetext{
${ }^{26}$ Halle, Josef A. A. van - Impressões de minhas viagens no Brasil. Rio de Janeiro, VeritasActualidades, 1876, p. 20.

${ }^{27}$ Machado de Assis - Quincas Borba. Op. cit., p. 9.
} 
da média de 1840-1849. Para os 161 escravos avaliados nos inventários de 1860-1869, teremos uma média de 3,22 escravos para cada inventariado (29,06\% da média dos anos 1840). Para os 156 escravos avaliados nos inventários de 1870-1879, a média será de 3,12 escravos para cada inventariado $(28,15 \%$ da média dos anos 1840$)$, que não é tão diferente da média da década anterior. E, finalmente, para os 62 escravos avaliados nos inventários de 1880-1888, a média será de apenas 1,24 escravos para cada inventariado $(11,19 \%$ da média dos anos 1840). (Ver Tabela VI).

Tabela VI. Números médios de escravos possuídos pelos inventariados, de acordo com os inventários consultados para o período 1810-1888.

\begin{tabular}{lccc}
\hline Décadas & $\begin{array}{c}\text { Número de } \\
\text { Inventários }\end{array}$ & $\begin{array}{c}\text { Número de } \\
\text { Escravos Avaliados }\end{array}$ & $\begin{array}{c}\text { Número Médio } \\
\text { descravos Possuídos }\end{array}$ \\
\hline $1810-1819$ & 50 & 357 & 7,14 \\
$1820-1829$ & 50 & 412 & 8,24 \\
$1830-1839$ & 50 & 414 & 8,28 \\
$1840-1849$ & 50 & 554 & 11,08 \\
$1850-1859$ & 50 & 319 & 6,38 \\
$1860-1869$ & 50 & 161 & 3,22 \\
$1870-1879$ & 50 & 156 & 3,12 \\
$1880-1888$ & 50 & 62 & 1,24 \\
\hline Média Geral & 400 & 2.437 & 6,08 \\
\hline Média $1810-1849$ & 200 & 1.737 & 8,68 \\
\hline Média $1850-1888$ & 200 & 698 & 3,49 \\
\hline
\end{tabular}

FONTE: ANRJ - Inventário

Op. cit., Para os Anos 1810-1888.

Todavia, para termos uma melhor idéia dos padrões de propriedade escrava entre os 104 inventariados possuidores de escravos desta segunda amostragem, será necessário conhecer o número de cativos que cada um deles possuía, o que também indica sua posição social e, talvez, venha refletir os padrões gerais de propriedade escrava na sociedade do Rio de Janeiro na segunda metade do século XIX.Vimos, anteriormente, que 96 inventariados não possuíam escravos, mas isso não significava que todos eles vivessem na mais absoluta pobreza. Os mais miseráveis eram apenas 36 inventariados, enquanto que outros sessenta possuíam diversas ocupações e situações financeiras. Entre os 104 inventariados possuidores de escravos, continuaram a predominar os "pequenos escravistas", ou seja, aqueles indivíduos que possuíam de um a dez escravos. Seu número era 85 e, apesar de ser inferior ao 
número dos "pequenos escravistas" da primeira amostragem, correspondia a $81,73 \%$ dos possuidores de escravos da segunda amostragem. Já os inventariados que possuíam mais de dez escravos chegavam somente a 19 , o que corresponde a $18,27 \%$ do total de senhores inventariados da segunda amostragem e menos da metade dos "grandes escravistas" da primeira amostragem. (Ver Tabela IV).

Estes dados refletem a manifestação de dois fenômenos bastante interligados. O primeiro deles era a redução do número de escravos que cada família possuía, como as médias decenais para o período 1850 1888 demonstram. O segundo fenômeno era o desaparecimento da categoria dos senhores de escravos integrada por aquelas "centenas e centenas de famílias" mais pobres, repetindo Ewbank, que possuíam um, dois ou mais escravos, que lhes forneciam integral ou parcialmente seu sustento. Estas famílias acharam mais conveniente se desfazer de seus escravos e aplicar o dinheiro em investimentos mais seguros. Inclusive, muitos desses indivíduos passaram a viver com o produto do seu próprio trabalho, pois, com o surgimento de grandes empresas comerciais, bancárias e de serviços urbanos, eles puderam encontrar funções consideradas mais "dignas", que não se nivelavam com aquelas exercidas pelos escravos e trabalhadores imigrantes. Com as modificações ocorridas a partir dos anos 1850 , não seria ousado afirmar que a propriedade escrava no Rio de Janeiro passou a concentrar-se nas mãos daqueles setores remediados e mais abastados da sociedade, que, diferentemente da atitude mais "moderna" do personagem Cristiano Palha, ainda mantiham-se aferrados a sua tradicional convicção escravista.

Entre os inventariados escravistas da amostragem de 1850-1888,61 indivíduos possuíam de um a cinco escravos e, com exceção de quatro deles que viviam do aluguel ou ganho de um ou dois escravos e de dois pequenos lavradores, podiam ser considerados de situação financeira remediada. Uma dessas exceções era o africano liberto Antônio Ferreira que, ao morrer em 1860, legou aos seus herdeiros dois cavalos, uma caderneta de poupança com pequena quantia no Banco Rural e um escravo africano. ${ }^{28}$ Entre os inventariados de situação financeira remediada, encontramos comerciantes, industriais, profissionais liberais, oficiais militares, religiosos, um funcionário público, indivíduos que viviam do aluguel ou ganho de cativos, do aluguel de imóveis ou de rendimentos de capital. (Ver Tabela IV).

${ }^{28}$ A NRJ - Inventários "post-mortem": Caixa 3989 - No. 8 (1860). 
Num dos contos de Machado de Assis, vamos encontrar um certo Justiniano Vilela que serve de estereótipo perfeito dos indivíduos pertencentes a esta "classe média baixa". Justiniano Vilela era funcionário público, ou melhor, chefe de seção aposentado, que vivia com um salário razoável, tinha uma casa e dois "molecotes". ${ }^{29}$ Bem próximos da situação do chefe de seção aposentado, estavam dois inventariados da nossa segunda amostragem. O primeiro deles era CaetanoJosé Barbosa do Couto Brum que, ao falecer em 1855, legou aos seus herdeiros algumas jóias, objetos de ouro e prata, vinte ações do Banco do Brasil, três apólices da dívida pública, uma ação do sofisticado Cassino Fluminense e três escravos. O outro, mais modesto, era o Major-Engenheiro José Maria Jacinto Rebelo que, ao falecer em 1871, legou aos seus herdeiros diversas jóias e quatro escravos. ${ }^{30}$

Já 24 inventariados da segunda amostragem possuíam de seis a dez escravos e, talvez com exceção de quatro indivíduos que viviam apenas do aluguel ou ganho dos seus cativos, podiam ser considerados como membros da "classe média abastada" ou "superior". Entre eles existiam um médico, um religioso que também era comerciante, indivíduos que viviam dos rendimentos de capital ou aluguéis de imóveis e aqueles, que além desses rendimentos, ainda exploravam o aluguel ou ganho de escravos. (VerTabela III). O viajante francês, François Biard, teve a oportunidade de ver passarem pela elegante Rua do Ouvidor muitas famílias que, pela sua descrição, pareciam se situar nesses setores médios mais abastados. Famílias estas que obrigatoriamente estavam acompanhadas por um séquito de escravos, como ainda era costume nos anos 1860 entre os escravistas convictos. Segundo Biard, na Rua do Ouvidor, mostravam

$"(\ldots)$ as lindas brasileiras seus vestidos caros, acompanhadas, como de praxe, de duas ou três mulatinhas, duas ou três negras, alguns molequinhos e molequinhas, tudo desfilando gravemente, o marido à frente". ${ }^{31}$

29 Machado de Assis - "As bodas de Luis Duarte", em Obras Completas, Volume II. Rio de Janeiro, Editora José Aguilar, 1962, p. 195.

${ }^{30}$ A NRJ - Inventários "post-mortem": Caixa 4063 - No. 792 (1885); e Caixa 4162 - No. 1882 (1871).

Biard, François - Dois Anos no Brasil. Primeira edição de 1862.Tradução de Mario Sete. São Paulo, Cia. Editora Nacional, 1945, p. 47. 
Encontramos em Dom Casmurro, de Machado de Assis, um perfeito estereótipo dos indivíduos desta posição social, alguns deles bem próximos dos setores mais ricos da sociedade. Este estereótipo é Dona Glória de Albuquerque Santiago, mãe de Bentinho, que, ao morrer o marido deputado, desfez-se de uma "fazendola" em Itaguaí e dos escravos que lá estavam, "comprou alguns que pôs ao ganho ou alugou, uma dúzia de prédios, certo número de apólices, e deixou-se estar na casa de Mata-Cavalos, onde vivera os dois últimos anos de casada". Na verdade, a casa de Mata-Cavalos era uma chácara que, apesar do bo m tamanho, não podia abrigar, por falta de espaço, todos os cativos que Dona Glória possuía, que talvez fossem até mais de dez. ${ }^{32}$

Próximos da situação de Dona Glória, estavam outros dois inventariados da nossa amostragem. O primeiro deles era o espanhol Pedro de Aguinaga que, ao falecer em 1858, deixou para seus filhos uma grande chácara com duas casas térreas na aristocrática Rua de São Clemente, em Botafogo, duas carruagens, 41 jóias de ouro com brilhantes, rubis e pérolas, 103 objetos de prata de diversos tamanhos, trezentas ações do Banco do Brasil, cinqüenta ações da Companhia de Seguros Marítimos e terrestres, 62 ações da Companhia de Paquetes Brasileiros, uma ação do Cassino Fluminense, muitos livros, quatro quadros com molduras douradas e oito escravos. A segunda pessoa era a viúva Constança Bernardina de Almeida, falecida em 1867, que deixou para seus filhos uma grande chácara com casa assobradada na Praia do Caju, um pequeno veículo, 93 objetos de prata de diferentes tamanhos, 2:769\$070 réis em dinheiro, três valiosíssimas apólices da dívida pública e oito escravos. ${ }^{33}$

Finalmente, encontramos na segunda amostragem 29 inventariados que eram proprietários de mais de dez escravos: treze que possuíam entre onze e vinte cativos e seis acima de vinte cativos. Com exceção de um indivíduo que vivia unicamente do aluguel ou ganho de escravos e de quatro lavradores das cercanias, que pelos bens possuídos e fontes de renda se aproximavam mais das camadas médias, os outros catorze inventariados podem ser considerados como membros dos setores mais ricos, do grana monde do Rio de Janeiro, ou como dizia Machado de Assis ao se referir à esplendorosa Natividade, mulher do banqueiro Agostinho Santos, "daquela dúzia de nomes planetários que

Machado de Assis - "Dom Casmurro", em Obras Complctas,Volume I. Op. cit.,p. 818. ANRJ - Inventários "post-mortem": Maço 188 - No. 3721 (1858); e Caixa 1385 - No. 1848 (1867). 
figuram no meio da plebe de estrelas". ${ }^{34}$ Entre eles estavam um grande comerciante, fazendeiros, um oficial militar que também era comerciante e tinha muitos imóveis alugados e, majoritariamente, indivíduos que combinavam os rendimentos do aluguel ou ganho de escravos com os rendimentos de capital ou aluguéis de imóveis. (Ver Tabela IV).

De acordo com Expilly, no início dos anos 1860 ainda era muito comum se encontrar aqueles "bons burgueses" cujo patrimônio se constituía de quinze, quarenta ou cinqüenta escravos, ocupando de seis a dez em tarefas domésticas e empregando os outros em atividades fora de casa, alugando-os, pondo-os ao ganho e ensinando ofícios aos "moleques". ${ }^{35}$ Contudo, acreditamos que as pessoas que possuíam acima de trinta escravos, e os alugavam ou empregavam no ganho, não passavam de um número muito reduzido na segunda metade do século XIX. É provável que as pessoas mais abastadas, que viviam dessa forma, tivessem um pouco mais de dez escravos, como exemplifica o inventário de João Martins Barroso, falecido em 1863, que deixou para seus herdeiros 22 escravos e seis grandes casas em diversos pontos da cidade. ${ }^{36}$

Também é provável que, na medida em que a abolição da escravatura se aproximava, não só os exploradores do aluguel ou ganho de cativos foram se reduzindo, como também se verificou uma grande redução no número de cativos dos "bons burgueses" que ainda continuaram com a mesma fonte de renda. Os inventários de Maria Rosa Botelho, filha do Barão de Sapucaia, e Mariana Gertrudes da Serra Burgos parecem refletir esse fenômeno. A filha do Barão de Sapucaia, falecida em 1879, era uma "fazendeira da cidade", tal como a personagem Fidélia, filha do Barão de Santa Pia, no Memorial de Aires de Machado de Assis. Ao morrer, esta senhora deixou para seus filhos catorze escravos, em sua maioria alugados ou ao ganho pelas ruas da cidade, além de uma fazenda fora da Corte e 6 casas na zona central. Já Mariana Gertrudes da Serra Burgos, falecida em 1887, deixou para uma filha oito escravos explorados naquelas modalidades, além de sete casas no centro da cidade, três terrenos, 86 ações de diferentes empresas e 1:000\$000 réis em dinheiro. ${ }^{37}$

Machado de Assis - Esaú e Jacó. Op. cit., p. 19.

Expilly - Le Brésil tel qu'il est. Paris, Charlieu et Huillery, Libraires-Editeurs, 1864, pp. $185-186$.

ANRJ - Inventário "post-mortem": Caixa $5463-$ No. 470 (1863).

Ibidem: Caixa 4208 - No. 1912 (1879); e Caixa 416-No. 1985 (1887); e Machado de Assis — "Memorial de Aires", em Obras Completas, Volume I. Op. cit.,p. 1.188. 
Parece bastante claro que nas duas metades do século XIX, existiram duas situações bastante diferenciados, no Rio de Janeiro, com relação à estratificação social e à distribuição da propriedade escrava. As amostragens que realizamos com os inventários post-mortem, apoiadas em relatos de viajantes e em algumas passagens da obra de Machado de Assis, refletem muito bem essas duas situações. De uma sociedade que se organizava com base no trabalho escravo e que definia suas formas de estratificação social em função do acesso à propriedade escrava e da sua distribuição entre os homens livres, começou a emergir, a partir da cessação do tráfico negreiro africano, uma nova sociedade, com o trabalho livre substituindo gradualmente o cativo e com o estabelecimento de novas formas de estratificação de seus membros. Assim, na segunda metade do século XIX, a propriedade escrava deixou de ser o mais importante fator de determinação da posição dos indivíduos, para dar lugar, gradativamente, a novos critérios de hierarquia social, "onde a nota tônica recaia", de acordo com Raymundo Faoro,"sobre as classes, definidas pelos haveres e orientadas no mercado". Este processo se consolidaria, evidentemente, após a abolição da escravatura em $1888 .^{38}$

Talvez, as amostragens realizadas tenham contribuído para reforçar uma interpretação impressionista da organização e das mudanças na sociedade urbana do Rio de Janeiro do século XIX, pois nosso maior objetivo não era a realização de uma exaustiva análise de estratificação social e, sim, esboçar alguns padrões ou a proporcionalidade da distribuição da propriedade escrava entre os diversos setores livres. Mas, ao realizar esta tarefa, acabamos discutindo, mesmo superficialmente, alguns elementos da problemática das hierarquias sociais. Por enquanto, ficamos satisfeitos em recolocar a questão e trazer material adicional para o debate.

\footnotetext{
${ }^{38}$ Faoro, Raymundo - Machado de Assis: a pirâmide e o trapézio. São Paulo, Cia. Editora Nacional, 1976, p. 33.
} 